This is a post-print version of a paper that appears in The Journal of Political Ideologies 7(2):pp. 163-177, 2002.

\title{
Feminism and the Politics of Difference in Northern Ireland
}

Adrian Little

Lecturer in Politics at Goldsmiths College, University of London

Address for correspondence:

Dr. Adrian Little

Department of Social Policy and Politics

Goldsmiths College

University of London

New Cross

London

SE14 6NW

Tel: (020) 79197906

Email: a.little@gold.ac.uk 
This is a post-print version of a paper that appears in The Journal of Political Ideologies 7(2):pp. 163-177, 2002.

\section{Feminism and the Politics of Difference in Northern Ireland}

Introduction: the constraints on feminism in Northern Ireland

Formal politics in Northern Ireland is often noted for its domination by men and low levels of electoral representation by women. This, of course, can be a simplistic picture of political participation as women have been extremely active in local and community politics in the province. However, whether on the formal level where the activism of women has increased in recent years or the more informal domain of the local community, such activism of women has not taken on a strong feminist dimension. ${ }^{1}$ Indeed the study by Miller et al (1996) points to the prevalence of stereotypical attitudes about feminism and even a distinct hostility, even amongst many women engaged in political campaigning that seeks to further the position of women. ${ }^{2}$ This article will examine the state of feminism in Northern Ireland by outlining some of the traditional constraints that it has faced in the province, and comparing feminist politics in Northern Ireland with some recent developments within feminist literature. I will conclude by indicating that, whilst feminists in Northern Ireland are becoming more attuned to 'the politics of difference', the dominant feature of feminism in the North to date is a strategic essentialism that resonates more with first wave feminism than contemporary feminist debates. ${ }^{3}$

Initially four major constraints can be identified that have impeded the development of feminism in Northern Ireland. Firstly, the most important obstacle has been the way in which traditional views of women and their role has prevented women from participating in formal politics. Here McWilliams notes that 'both Church and State have combined together in ensuring that the prime role of women is as housewives and mothers. In the face of such traditional Catholic and Protestant fundamentalism it has proved extremely difficult for women to organise around 
This is a post-print version of a paper that appears in The Journal of Political Ideologies 7(2):pp. 163-177, 2002.

issues which are of personal and political importance to them'. ${ }^{4}$ It is clear that the centrality of religion as a major source of identity has constrained the opportunities for women to make a major impact in the public sphere (especially as the churches play a prominent role in the secular life of the province). The second impediment to feminist politics in the province has been the closure of spaces for political debates and the prevalence of a narrow definition of what is political. This manifests itself in a 'politics of avoidance' whereby politics becomes a dirty word and is understood as being related only to issues of nationality and ethnic or religious identification. ${ }^{5}$ This closure of 'the political' has affected all radical political movements in Northern Ireland that try to invigorate debates that are not primarily concerned with constitutional arrangements.

The third constraint on feminist politics stems from the dominance of the traditional labels of Northern Irish politics. Thus any alternative political position is often recast in the light of dominant signifiers. In the case of feminism, with its challenge to the organisation of the political system, there has been a linkage established in the mind of some with nationalism. For this reason 'unionism has seen feminism as alien and viewed it with suspicion. The ties of unionism to the ascendancy have traditionally placed it on the side of the status quo'. ${ }^{6}$ The problem for feminism then, is to demonstrate the ways in which it can articulate a range of concerns that may include nationalist positions but which also provides spaces for other understandings of the problems women face in Northern Ireland. The final obstacle to the development of feminism relates more generally to a scepticism of political ideas in the province. Here we see political discourses dominated by the practical problems of political reality in Northern Ireland and the need to get things done on the ground which is sometimes manifest as an anti-intellectualism. Put simply, highflown, ethereal debates about philosophical principles tend to be overridden by realpolitik. For those aligned with feminism, this may manifest itself in challenging the real patriarchy of Northern 
This is a post-print version of a paper that appears in The Journal of Political Ideologies 7(2):pp. 163-177, 2002.

Irish politics and society and the everyday issues that women face rather than engaging in academic debates about essentialism and the politics of difference, for example.

Of course, these are very real problems and constraints but this article contends that a broader, more complex understanding of feminism needs to be developed if it is to have a more fundamental impact upon politics in Northern Ireland. Insofar as it has been articulated at all, the politics of difference in Northern Ireland has manifested itself in terms of equal respect and rights for the 'two traditions' in the province (see the provisions of the 1998 Belfast Agreement). Thus the idea of diversity has only been understood in terms of the traditional schisms and dividing lines of Northern Irish society with little attention given to the needs and concerns of minority ethnic groups, gays and lesbians, the disabled and so on. ${ }^{7}$ In most liberal democracies feminists have made a vital contribution to the public understanding of diversity and the problems of articulating a politics of difference. Unfortunately, in the context of Northern Ireland, this contribution has not been as notable and its impact has been negligible due to the kinds of constraints outlined above. Sales suggests that 'sectarianism, and the construction of political and social life around community loyalties, has been a powerful force in maintaining women's subordination'. ${ }^{8}$ This article examines these problems and articulates ways in which a rethinking of feminism can help to challenge the closure of political debates in Northern Ireland and contribute to a better public understanding of the political differences that exist there.

This is not to say that feminists in Northern Ireland are unaware of the politics of difference. ${ }^{9}$ However in establishing a primary strategy of advancing the participation and representation of women, some of the problems associated with diversity and its implications for political organisation have been overlooked. Indeed there is a distinct danger that the politics of difference may come to be seen only within the rather narrow liberal parameters and discourses that 
This is a post-print version of a paper that appears in The Journal of Political Ideologies 7(2):pp. 163-177, 2002.

have dominated the peace process. Here the dominant language, influenced by theorists such as John Rawls and Jurgen Habermas, is of tolerance, parity of esteem, state neutrality and so on. Whilst these ideas have been highly influential in debates on the politics of difference, they have come under sustained criticism from radical democrats and feminists such as Chantal Mouffe who believe that diversity gives rise to a number of problems that cannot be easily accommodated within dominant strands of liberalism. ${ }^{10}$ Mouffe's perspective suggests that such are the relations of power that permeate contemporary liberal democracies that conflict and tension is an inevitable feature of those societies. This implies that the politics of difference is unlikely to be experienced within the consensual models of liberalism which are based on toleration and accommodation. Mouffe's anti-essentialist feminism focuses on diversity as a catalyst in the struggle between groups in liberal democratic society which is itself an unavoidable outcome from the tension that emanates from the uneven distribution of power and the claims of democracy. The difficulties identified in Mouffe's theory reflect the traditional arguments within feminism between universalism and essentialism on the one hand, and particularism and diversity on the other. ${ }^{11}$ Her work demonstrates the problems that emerge when grand claims are made about women as a singular whole particularly with respect to the different experiences, conflicts and exclusions that varying women may experience.

In this context the use of the language of difference by feminists in Northern Ireland needs to be more directly articulated. More specifically there needs to be a clearer expression of the ways in which a commitment to difference manifests itself in Northern Ireland and a recognition of the ways in which support for diversity might conflict with the strategic essentialism that feminists in the province have employed. On top of this there also needs to be a more coherent expression of the particular version of the politics of difference that feminists in Northern Ireland subscribe to. Here the schism between the procedural liberalisms of Rawls and Habermas and the radical democratic 
This is a post-print version of a paper that appears in The Journal of Political Ideologies 7(2):pp. 163-177, 2002.

critique derived from Mouffe is paramount. Serious engagement with this debate is likely to show up the divisions within feminist politics in Northern Ireland rather than the unified, consensual voice that an essentialist feminist approach might imply.

\section{Contemporary Feminism in Northern Ireland: The Problem of Essentialism?}

The problems of essentialism and difference permeate feminist perspectives on Northern Ireland. Some feminist discourses in Northern Ireland are couched in essentialist terms insofar as they believe that there are definitive characteristics to the experience of all women in the province regardless of religion, culture, nationality and so on. If this is the case then feminists can develop a universal position in which they can pursue whatever version of rights and/or equality they believe in without difficulty. Few commentators however believe that there is a universal experience for women in Northern Ireland given that different sources of identity cross-cut gender to individualise the condition of different women. This is not to say that all women do not face inequalities and patriarchy but that the way in which they are experienced depends on a range of characteristics and competing sources of the self. The experience of the 'two communities' impact severely on the everyday lives of women not least in the areas of culture and religion. Sales notes that 'much of the literature about women has been silent on the question of religious divisions, making the tacit assumption that women are oppressed as a gender, but their experiences as women are basically

similar'. ${ }^{12}$ She opposes this view and argues that religion has a fundamental impact on women and their perception of gender politics. A key dividing line here has been the tendency of feminists within the predominantly catholic nationalist community to tie together their pursuit of gender equality with an anti-imperialist stance towards the British state as these are seen as mutually supportive forms of oppression. ${ }^{13}$ 
This is a post-print version of a paper that appears in The Journal of Political Ideologies 7(2):pp. 163-177, 2002.

However we should be careful about prescribing the ways in which religion, culture or nationality impact upon women. Just as there are differences between the experiences of Catholic and Protestant women and republicans and loyalists, there are also differences and variations within each of these categories. ${ }^{14}$ Thus whilst religion, for example, is a very important source of identity in Northern Ireland, it is not prescriptive. Women can be more or less Catholic or Protestant; they can let their religion have a more or less central role in their lives. In this sense religion is vital to an understanding of the way in which many people make sense of their lives in Northern Ireland, but the identity that is derived from religion is contingent. Whilst religion undoubtedly constrains space for the articulation of feminist politics, many feminists do manage to combine their political outlook with religious attachments. Religion, ultimately, is one source of identity amongst others and the impact of religion on any individual's identity will be different from that of another. Whilst more women may subscribe to religious identification in Northern Ireland than in many other liberal democracies, the extent to which those religions affect individual identity and behaviour is highly variable.

What emerges out of this complicated picture is a scenario in which we can identify the competing problems of essentialism and difference in Northern Ireland. Many women have been quick to point to the differing experiences of the 'two traditions' and therefore there has been some scepticism about essentialist accounts of the experience of women. However such is the stranglehold of the 'two traditions' model that wider visions of difference do not come into play. Rather than the critique of essentialism generating a sophisticated politics of difference, the 'two traditions' model of analysing Northern Irish politics closes political space and limits our understanding of diversity. Moreover it shrouds our understanding of difference within the two traditions and prescribes communal identities in a way that neglects schisms of gender, class, age and so on. ${ }^{15}$ The problem of prescribing women's identities has been most vociferously expressed 
This is a post-print version of a paper that appears in The Journal of Political Ideologies 7(2):pp. 163-177, 2002.

by nationalist feminists who fear that the homogenisation of women in Northern Ireland acts to over-simplify the diverse experiences of women in the province and could lead 'to a lowest common denominator kind of politics'. ${ }^{16}$ This is not a sentiment that uncritically subscribes to the 'two traditions' model because it rejects any kind of essentialisation of women's experience. Rather it implies that a strong feminist politics must be one that can articulate its differences as a matter of strength rather than engaging in the fruitless pursuit of an illusory common ground. ${ }^{17}$

Many of the analyses of the problems that women, and in particular, feminists face in Northern Ireland have centred upon the male-dominated, patriarchal relations that permeate life there. In particular Miller et al and McWilliams have noted the specific problems that face Protestant women due to the male-centredness of their church and the political representatives that have emerged from that tradition. ${ }^{18}$ Indeed Sales notes that the 'political face of the Protestant community is overwhelmingly male, represented by male political and Church leaders, most of them with strongly anti-feminist views'. ${ }^{19}$ Undoubtedly there is a fervent animosity towards women in public life within the Protestant churches and a scepticism about the value of what are regarded rather negatively as 'women's issues' in unionist politics. However, despite the stronger historical links between nationalism and feminism, the Catholic church has also obstructed the development of feminist politics. This is evidenced by the way in which Sinn Fein has often vacillated on its policy on abortion due to conflicting pressures from feminists in the republican movement and the conservative stance of the Catholic church. ${ }^{20}$ A further problem is not just that religion casts a pervasive shadow across the denominational divides but also, just as a certain kind of conservatism dominates Northern Ireland politics generally, so such a conservatism also pervades women's issues. For example, Sales notes how despite the spread of women's centres within the different communities in Northern Ireland, real difficulties have remained for lesbian women in achieving support due to the prevalence of rather ingrained conservative values. ${ }^{21}$ In these circumstances 
This is a post-print version of a paper that appears in The Journal of Political Ideologies 7(2):pp. 163-177, 2002.

feminist politics cannot merely focus on articulating the voice of women; it must also go about providing a radical challenge to some of the prevailing voices amongst women in Northern Ireland. Behind the rhetoric of diversity, there is a danger that feminist politics in Northern Ireland remains too focused on essentialist objectives that actually shroud diversity in practice.

The debate about essentialism and difference continues unabated in feminist theory and in that sense Northern Ireland is not unusual but the fact that politics there has been so maledominated has meant that some of the achievements of feminism in other liberal democracies have yet to be experienced in the province. In this scenario it is not surprising that essentialism remains a strong feature of Northern Irish feminist discourses. However in recent years the politics of difference has become increasingly prominent in feminist debates. ${ }^{22}$ Whilst feminism in Northern Ireland has been notable in recent years for the interaction between academics and women activists on the ground, it remains the case that the rhetoric of difference only relates to the fact that there is an acceptance of diversity in terms of religious persuasion and constitutional politics. Underpinning this narrow definition of diversity lies a strong essentialism which implies that male politicians have let the province down and that the participation of women would improve dialogue. Thus, according to Wilford, even 'die-hard' members of any community 'find little difficulty in asserting the existence of a "sisterhood" within the province, albeit one that chimes with notions of female essentialism and with traditional assumptions about gendered family roles'. ${ }^{23}$ In this sense the growing use of the language and politics of difference should not disguise the prevailing essentialism in Northern Irish feminism. Whilst this might not seem to be problematic, it has a fundamental effect on the nature of feminist politics:

women cannot speak with one voice. The conflict, and therefore the peace, has had different meanings for different women. The separation of "women's issues" from the mainstream 
This is a post-print version of a paper that appears in The Journal of Political Ideologies 7(2):pp. 163-177, 2002.

constitutional issues places limits on women's agenda, and risks marginalising women's voices'. $^{24}$

In short, the very real danger that feminists must avoid is being corralled into 'women's issues' when their real agenda is much broader and provides new perspectives across the spectrum of contemporary issues that face Northern Ireland. Thus feminists can and should have a significant impact on the political culture of Northern Ireland but, in the longer term, this necessitates a shift beyond essentialism and the articulation of a more radical politics of difference.

\section{Breaking the Mould? The Northern Ireland Women's Coalition}

The patriarchal domination of men and the resultant relative absence of women from the formal arena of representative politics has undoubtedly resulted in an emasculation of the idea of 'the political' in Northern Ireland. Where many women have been active in community politics, the issues raised have often been neglected or ignored in the formal political arena. This has led to a closure of politics where it becomes narrowly defined as concerned with constitutional issues alone. This understanding of politics which is built 'around community loyalties gives little space for raising other forms of inequality. This is particularly problematic for feminists, whose demands may conflict with established values within the community'. ${ }^{25}$ The emasculation of politics then is not only manifest in the focus on issues that are not always the primary concern of feminists, but it also perpetuates closure by building obstacles to greater feminist participation in the decisionmaking process. The problem is not just one of getting more women represented in formal politics but of changing the very way in which politics takes place. Sales notes how female representatives from the traditional parties in Northern Ireland have tended to let their party loyalties override gender issues. ${ }^{26}$ In this sense there is a need to open out political spaces to enable gender issues to 
This is a post-print version of a paper that appears in The Journal of Political Ideologies 7(2):pp. 163-177, 2002.

be discussed outside of the parameters of narrow constitutional politics. The most notable attempt to reconstruct the political in such a way has been the participation of the Northern Ireland Women's Coalition (NIWC) in the formal political arena since the 1990s. ${ }^{27}$

The NIWC has attempted to articulate the voices of different women in Northern Ireland and to provide a contribution to the process of changing the political culture in the province. In these aims it has been successful although the extent to which it has managed to establish a politics of difference is more questionable. Indeed, not surprisingly given the limited impact of women in formal politics, the NIWC has veered towards essentialist strategies and interpretations of women. Nonetheless the party has used the language of diversity and has played upon the existence of 'a deliberate cross-community base' alongside an ethical framework 'organised around three core principles of human rights, equality and inclusion'. ${ }^{28}$ Thus the NIWC has consciously decided to focus on the ethical framework rather than establishing a comprehensive ideology. ${ }^{29}$ The agenda then was to focus on the need for political engagement and to encourage a process of dialogue. The NIWC wanted to provide a motor for the expression of the concerns of women but, more directly, it wanted to ensure that procedures were established in which some kind of accommodation could be reached by everyone in Northern Ireland. For this reason the NIWC has been highly supportive of the peace process in Northern Ireland and the various initiatives that have furthered political engagement, in particular the 1998 Belfast Agreement. Here we can note Fearon's enthusiasm for the provisions on equality and rights in the Agreement and the establishment of a Civic Forum that would allow further opportunities for women to participate in decision making beyond the Northern Ireland Assembly. ${ }^{30}$

The NIWC has provided a fresh perspective in Northern Irish politics that unfortunately has traditionally been missing. It is worth noting especially the concerns that they have raised about the 
This is a post-print version of a paper that appears in The Journal of Political Ideologies 7(2):pp. 163-177, 2002.

general problems and the impact on Northern Ireland in particular of measures initiated by the Labour government since 1997 such as the New Deal and the Working Families Tax Credit. ${ }^{31}$ Here they have been able to articulate some of the very particular problems that affect Northern Ireland as it negotiates the current conflict. However their success in establishing a political voice on these issues results from the fact that they have been able to construct an essentialist position on these issues with regard to their impact upon women. Thus Sales has noted that quite consciously the NIWC recognised their differences over constitutional issues and therefore 'agreed to work together on matters where they could unite, such as childcare and employment opportunities'. ${ }^{32}$ Whilst it is important that their position on these issues is expressed, it is nonetheless instructive that rather than building upon their differences, they elected to focus on points where little difference existed. This may reflect the realities of exercising political influence but it doesn't quite amount to a politics built upon 'heterogeneity' and a liberating 'acknowledgement of difference'. ${ }^{33}$ The acknowledgement of difference is welcome but this is not inimical to a politics built on difference; in many respects the NIWC still remains constrained within the traditional parameters of Northern Irish political debate. It is not that it ignores divisive issues but rather that it attempts to make differences less conflictual. Thus Fearon and McWilliams argue that 'consciously choosing not to ignore the conflict has paradoxically helped to keep conflict in check'. ${ }^{34}$ It seems that the NIWC harnesses its strengths and influence by choosing not to concentrate on what divides them and that this helps to manage conflictual relations. Sadly it is what divides them that constitutes the major political schism in Northern Irish society.

This is not to denigrate the impact of the NIWC on the issues it has decided to concentrate upon but merely to signal the way in which they have followed a rather essentialist strategy whilst simultaneously building discourses built on diversity. The problem of course is that this approach cannot override sectarianism or the political dominance of constitutional questions and many 
This is a post-print version of a paper that appears in The Journal of Political Ideologies 7(2):pp. 163-177, 2002.

women, especially nationalists, will continue to argue for 'the integration of women's issues with the constitutional debate'. ${ }^{35}$ It is perhaps wise then not to make too many grand claims about the impact of the NIWC on the construction of a politics of difference. Its primary impact has been on the rather essentialist but strategically significant ground of opening up political spaces for women. Fearon has admitted as much in welcoming the Belfast Agreement for lifting 'the veil on politics' and acting as 'the catalyst for women asserting a "claim of right" to full and equal political participation. It may take several generations before this claim is realised, and with it its full import: a truly inclusive polity that reflects and revels in the diversity of its population'. ${ }^{36}$ The sentiment here is correct. More participation and representation by women does not equate to a feminist politics of difference. Such an aspiration is worthy but clearly does not reflect the contemporary reality in Northern Ireland. The NIWC has succeeded in challenging the 'conventional shibboleths and nostrums that have condemned the province to murderous stalemate ${ }^{37}$ but actually changing the political culture and constructing a politics of difference is a much more difficult task to achieve.

To summarise then, the major contribution of the NIWC has not been in establishing diversity or even in confronting the differences within the party itself. On the contrary its achievement is mainly procedural and lies in:

a certain female essentialism, but not in the unreflective (and untrue) sense that only women are concerned about achieving peace. Rather, the NIWC presented itself as an exemplar of the need for inclusiveness and pluralism in seeking a political settlement, reflecting the fact that the wider women's movement has successfully accommodated diversity in seeking equal status for women. In effect, the Coalition's platform drew inspiration from the shared 
This is a post-print version of a paper that appears in The Journal of Political Ideologies 7(2):pp. 163-177, 2002.

and sometimes difficult experiences of ideologically distinctive feminists who have reconciled their doctrinal differences in pursuit of a common good. ${ }^{38}$

The NIWC has emphasised the need for a new kind of politics in Northern Ireland but as yet the full and radical implications of feminist interpretations of democracy and difference have not been manifest in the party itself or the wider stage of Northern Irish politics and society. Given their participation in the current peace process, it is perhaps not surprising that the NIWC employs the dominant discourses of 'conflict resolution', 'reconciliation', and 'post-conflict reconstruction'. ${ }^{39}$ Nonetheless it is important from a radical democratic perspective to recognise that some of the differences in Northern Ireland will prove to be irreconcilable. The question of the feminist movement will then be not 'how do we end our conflicts?' but rather 'how do we construct a politics in which our conflicts are effectively negotiated and managed?'

$\underline{\text { Feminism and the reconstruction of the political }}$

The NIWC has made a strong contribution to the essentialist objective of opening spaces for women to participate politically. Of course the party is still a relative newcomer in the political arena and it would be wrong to expect it to achieve objectives concerned with shifting the very fabric of the political culture in which it is involved in such a short space of time. Nonetheless it is worth noting that a clear feminist picture of diversity is yet to emerge in Northern Ireland. This reflects the cultural particularity of feminist politics and the perennial dangers of asserting that feminism should prescribe a universal set of political values on different kinds of society. In this vein Coulter has pointed out how 'feminism ... has been limited by its own origins in western Europe and the United States, and its projection of the experiences and interests of essentially middle-class, white women on to the rest of the world'. ${ }^{40}$ The everyday experiences and political 
This is a post-print version of a paper that appears in The Journal of Political Ideologies 7(2):pp. 163-177, 2002.

realities of Northern Irish politics will shape the kinds of feminist politics that emerge there. One such notable feature is the way in which women's political activism has been most identifiable within working class and deprived communities in the province when feminism in other liberal democracies is often regarded as middle class territory. One reason for this has been the ways in which women have experienced social deprivation and the outcomes of political violence. Thus McWilliams, for example, notes that for 'women in Northern Ireland one of the most glaring features of life is the hardship of poverty with all its social, financial and psychological repercussions ... It is against such a background that the term "feminisation" of poverty takes its meaning'. ${ }^{41}$ At the same time the experience of women in raising families in the context of the murder or imprisonment of their partners has led to a particularity about the development of feminist politics in Northern Ireland.

The combination of challenging patriarchy and the particular impact of living with political violence for such a long time offers a unique voice for feminism in Northern Ireland. Nonetheless the difficulties of articulating this feminist voice remain. For example, many feminists have argued that a society trying to come to terms with violence needs to broaden the parameters of their debate to examine issues such as domestic violence as well as the behaviour of paramilitaries and/or the security forces. However the dominance of the traditional divide makes it extremely difficult to achieve such a broadening of debate. Thus, whilst there is a pathway towards a clearer feminist voice, we must also recognise that '[s]ectarian divisions are built into the structures and identity of Northern Ireland. Politics has remained polarised around community loyalties, placing severe limitations on the development of class-based or gender-based loyalties'. ${ }^{42}$ The danger of this scenario is that feminist politics can develop a virtuous circularity whereby the political system exhibits a closure of the political and, in order to enter political debate and try to open it up, feminists have had to agree to place less emphasis on the very issues that dictate the political 
This is a post-print version of a paper that appears in The Journal of Political Ideologies 7(2):pp. 163-177, 2002.

closure. The perils in many cross-community initiatives in Northern Ireland is that they circumnavigate what they see as 'politics' to avoid conflict. This runs the risk of parallel worlds emerging in which the existence of conflict is never properly understood and the sources of it are divorced from other sources of identity and social cleavages. Such avoidance of conflict is unlikely to be able to find a means of making it socialised or bearable. It is for this reason that Sales argues that 'unless women are involved with politics as it is traditionally defined in Northern Ireland, their influence is likely to remain marginal. If women are to reconstruct the meaning of politics in Northern Ireland, they face the even more difficult task of engaging with the issues which divide them'. ${ }^{43}$

This takes us to the nub of the issue when it comes to thinking about the implications of a feminist politics of difference for democracy. Political discourses in Northern Ireland have consistently been littered with discussion of ways to 'end' or 'resolve' the conflict when, in fact, such an objective may not be possible. Perhaps it might be more useful to think about how we might 'contain', 'manage' and 'negotiate' conflict instead of entertaining half-baked dreams of what it would be like without political contestation. Indeed conflict is so ingrained in Northern Ireland that we must think more clearly about what we expect democratic politics to achieve. It is in this context that we can note the attraction of deliberative models of democracy to some feminists in Northern Ireland. Whilst noting the obstacles to a feminist transformative process, Elisabeth Porter sets out four principles for an inclusive democratic dialogue across difference: that equality and difference are not incompatible, that identities in Northern Ireland are partial and multiple, that political dialogue can establish solidarity, and that there should be respect for diversity. ${ }^{44}$ None of these criteria are objectionable in themselves but, like other attempts to inculcate Habermasian discourse ethics and deliberative democracy in the context of Northern Ireland, they are very difficult to apply in practice. ${ }^{45}$ The major difficulty with such approaches is the tendency to 
This is a post-print version of a paper that appears in The Journal of Political Ideologies 7(2):pp. 163-177, 2002.

imagine perfectionist scenarios that override some of the complex realities that actors on the ground are forced to deal with. In the case of Porter, she argues against distrust and suspicion when in divided, conflictual societies, such factors are likely to be unavoidable and indeed definitive of social relations. ${ }^{46}$ Moreover her advocacy of a critical understanding of difference that doesn't permit 'victimization, intimidation or oppression' may be desirable but it doesn't reflect the reality of dealing with the divisions in Northern Irish society. ${ }^{47}$

A realistic embrace of democracy in divided societies cannot rely on dialogue and discussion resolving sources of conflict especially where those differences are as incommensurable as in Northern Ireland. Where essentialist feminism might argue that women are better at dialogue and that men in Northern Ireland have impeded conflict resolution by their failure to engage sufficiently with each other, a more radical view would have it that women should be involved because they have a range of contributions to make to the debate but that they are no more likely to be able to find some kind of solution to the intractable problems just because they are women. Unfortunately in Northern Ireland there remain pipe-dreams that everything would be fine if only everyone could sit down and talk to one another. Whilst dialogue is important and to be encouraged, we need to be careful about asserting the perfectionist outcomes of such discussion. Where sometimes negotiation may generate some kind of agreement, frequently it will not. Democracy is imperfect and so it is unlikely that consensual agreements will emerge in Northern Ireland on the simple basis that there is dialogue. In terms of feminism these sentiments are aptly expressed by Eilish Rooney:

Representative democracy, politics and gender in the north of Ireland are enmeshed within the hierarchies of power and inequality, which are differently experienced and differently understood by differently positioned women. Seeing women in politics in the north of 
This is a post-print version of a paper that appears in The Journal of Political Ideologies 7(2):pp. 163-177, 2002.

Ireland simply as an excluded group fails to reflect the complexities of women's presences, absences and agency within the historically specific, politically and culturally sedimented hierarchies of sectarian politics which have shaped the state since its beginnings. ${ }^{48}$

From a radical democratic perspective, these sources of disagreement and contestation should not impede feminist politics but instead should provide opportunities to challenge the nature of Northern Irish political culture. The insistence of the NIWC on the importance of dialogue even with those with whom we share little demonstrates that it is well placed to articulate a rejuvenated democratic politics. Indeed Sales notes that since the 1990s there has been 'tentative discussion of "difference"' amongst feminists in Northern Ireland'. ${ }^{49}$ But if feminists are to seize the initiative offered by a politics of difference, then they must be prepared to grapple with their own diversity in the public eye. The diversity within the feminist movement must be used as a signifier of strength; it should be an indicator of the existence of the conditions of mature democracy in Northern Ireland whereby difference is not solely understood through the lens of the 'two traditions' political culture. A space has been opened in the male-oriented, patriarchal politics of Northern Ireland and groups like the NIWC have been at the forefront of the strategy of widening the participation of women. Now there is a need to move beyond this strategic essentialism and recognise that any 'attempt to impose a single voice on women in Ireland, North or South, Protestant or Catholic, will drive women away from expressing their needs, which will inevitably vary according to class, geography and urban or rural background'. ${ }^{50}$

\section{$\underline{\text { Conclusion }}$}

The development of feminist politics in Northern Ireland and the recent experiences of the NIWC have shown up some of the fundamental problems of the nature of 'the political' in the 
This is a post-print version of a paper that appears in The Journal of Political Ideologies 7(2):pp. 163-177, 2002.

province. Warm words abound about 'reconciliation', 'parity of esteem' and 'resolving the conflict' which, whilst using the language of liberal democratic politics, neglect the ingrained contestations of politics in the province and the way that the identities that underpin conflict are likely to be strengthened during the search for political accommodation. This provides a particular problem for feminist politics because, whilst feminists subscribe to the discourse of a politics of difference, they can find it difficult to express the diversity within their ranks. Indeed, perhaps more than any other group, feminists are in a position to confront Northern Irish political culture with its limitations and to provide a challenge to the ingrained differentials of power within the province. This involves not only a rethinking of 'the political' by the participants within Northern Irish politics but also by the two governments in their pursuit of a peaceful resolution of the conflict. The message that feminists need to articulate is that the 'agenda of reconciliation, assiduously promoted by official bodies, is based on the assumption that there are no differences of power. It also presents the state as a neutral arbiter, and prevents women from confronting issues of state violence and breaches of human rights'. ${ }^{51}$ This idea provides a sound foundation on which to criticise the liberal democratic model of consensus politics that has been constructed in Northern Ireland, whilst simultaneously reflecting the continued durability of the different ideological interpretations of the conflict there.

Such a critique of the political culture of Northern Ireland offers not only a basis on which to argue for a redefinition of 'the political' in the province but also a central role for feminists in creating the necessary changes. Contemporary feminists in Northern Ireland have been keen to ensure that their politics of difference does not lapse into a relativist free for all but focuses instead on the primacy of dialogue and the creation of a coalition based around negotiated principles. ${ }^{52}$ Moreover they have also suggested that there needs to be an opening of political spaces ('transitional spaces') in which dialogue can take place and that these spaces for negotiation will be subject to review and critical debate. Thus there is no assumption of fixity in the procedures for 
This is a post-print version of a paper that appears in The Journal of Political Ideologies 7(2):pp. 163-177, 2002.

engagement or the identities of the individuals involved. ${ }^{53}$ These theories of opening political spaces provide a dynamism in feminist politics in Northern Ireland that could build upon the strategic essentialist gains that have been made to date by the NIWC. However this requires feminists to confront their differences (and the power differentials which in part give rise to them) and demonstrate the ways in which their political organisation can allow such diversity to flourish without diluting their overall message. This objective would have a fundamental impact on Northern Irish political culture and thereby signify the reclaiming of 'the political' and the public sphere by feminists from those who have closed political spaces in Northern Ireland by denying difference and through the construction of the 'two communities' model.

\section{Notes and references}

1. In the 2001 General Election three women MPs were elected (Sylvia Hermon for the Ulster Unionists, Iris Robinson for the DUP, and Michelle Gildernew for Sinn Fein). Women such as Bairbre de Brun (Sinn Fein) and Brid Rodgers (SDLP) have also established a high proé le in the Northern Ireland Assembly and the Northern Ireland Women's Coalition has played a pivotal role in the peace process.

2. See R. L. Miller, R. Wilford and F. Donoghue, Women and Political Participation in Northern Ireland (Aldershot: Avebury, 1996).

3. On the politics of difference, see I. M. Young, Justice and the Politics of Difference (Princeton, NJ: Princeton University Press, 1990); A. Baumeister, Liberalism and the 'Politics of Difference' (Edinburgh: Edinburgh University Press, 2000); and C. Roulston and C. Davies (Eds), Gender, Democracy and Inclusion in Northern Ireland (London: Palgrave, 2000).

4. M. McWilliams, 'Women in Northern Ireland: an overview', in E. Hughes (Ed.), Culture and Politics in Northern Ireland (Buckingham: Open University Press, 1991), p. 81. 
This is a post-print version of a paper that appears in The Journal of Political Ideologies 7(2):pp. 163-177, 2002.

5. The term 'politics of avoidance' is used by R. Sales, Women Divided: Gender, Religion and Politics in Northern Ireland (London: Routledge, 1997).

6. Sales, ibid., p. 200.

7. The dominance of the traditional divisions on political discourses in Northern Ireland is reflected in the analysis of power, conflict and emancipation in the province provided by Joseph Ruane and Jennifer Todd. Feminism is only mentioned within the paradigm of the traditional conflict and feminists are referred to as 'marginals' who have 'distanced themselves not simply from the dominant culture and politics of their community but from any politics specific to Northern Ireland or any attempt to reform a particularly "Northern Irish" political culture': J. Ruane and J. Todd, The Dynamics of Conflict in Northern Ireland: Power, Conflict and Emancipation (Cambridge:

Cambridge University Press, 1996), pp. 79-80.

8. Sales, op cit., Ref. 5, p. 4.

9. See, for example, Roulston and Davies, op. cit., Ref. 3.

10. See C. Mouffe, The Democratic Paradox (London: Verso, 2000). See also A. Little, The Politics of Community: Theory and Practice (Edinburgh: Edinburgh University Press, 2002), and A. Little, 'Community and radical democracy', Journal of Political Ideologies, forthcoming, 2002. 11. See, for example, L. Nicholson (Ed.), Feminism/Postmodernism (London: Routledge, 1990); A. Phillips, Which Equalities Matter? (Cambridge: Polity Press, 1999); and J. Freedman, Feminism (Buckingham: Open University Press, 2001).

12. Sales, op. cit., Ref. 5, p. 9.

13. See C. Coulter, 'Feminism and nationalism in Northern Ireland', in D. Miller (Ed.), Rethinking Northern Ireland: Culture, Ideology and Colonialism (London: Longman, 1998).

14. See some of the different experiences expressed in E. Fairweather, R. McDonough and M. McFadyean, Only the Rivers Run Free: Northern Ireland, The Women's War (London: Pluto Press, 1984). 
This is a post-print version of a paper that appears in The Journal of Political Ideologies 7(2):pp. 163-177, 2002.

15. See C. Coulter, Contemporary Northern Irish Society (London: Pluto Press, 1999).

16. Coulter, op. cit., Ref. 13, p. 175; see also C. Hackett, 'Self-determination: the republican feminist agenda', Feminist Review, 50 (1995), pp. 111-116.

17. Coulter, op. cit., Ref. 13, p. 175.

18. Miller et al., op. cit., Ref. 2, p. 219. See also M. McWilliams, 'Struggling for peace and justice: reflections on women's activism in Northern Ireland', Journal of Women's History, 6/4 (1995), pp. 13-39.

19. Sales, op. cit., Ref. 5, p. 5.

20. Sales, ibid., p. 175.

21. Sales, ibid., p. 190.

22. See the various contributions to Roulston and Davies, op. cit., Ref. 3, especially that of Elisabeth Porter.

23. R. Wilford, 'Women and politics', in P. Mitchell and R. Wilford (Eds), Politics in Northern Ireland (Oxford: Westview, 1999).

24. Sales, op. cit., Ref. 5, p. 196.

25. Sales, ibid., p. 170.

26. Sales, ibid., p. 179.

27. For discussions of the origins and participation of the NIWC, see K. Fearon, 'Whatever happened to the

women? Gender and peace in Northern Ireland', in M. Cox, A. Guelke and F. Stephen (Eds), A Farewell to the Arms? From 'Long War' to Long Peace in Northern Ireland (Manchester: Manchester University Press, 2000); K. Fearon and M. McWilliams, 'Swimming against the mainstream: the Northern Ireland Women's Coalition', in C. Roulston and C. Davies (Eds), Gender, Democracy and Inclusion in Northern Ireland (London: Palgrave, 2000); McWilliams, op. cit., Ref. 4; and M. McWilliams and A. Kilmurray, 'Athene on the loose: the origins of the 
This is a post-print version of a paper that appears in The Journal of Political Ideologies 7(2):pp. 163-177, 2002.

Northern Ireland Women's Coalition', Irish Journal of Feminist Studies, 2 (1997), pp. 1-21.

28. Fearon, op. cit., Ref. 27, p. 153.

29. Fearon and McWilliams, op. cit., Ref. 27, p. 132.

30. Fearon, op. cit., Ref. 27, pp. 154-156.

31. Fearon, ibid., p. 157.

32. Sales, op. cit., Ref. 5, p. 195.

33. Fearon, op. cit., Ref. 27, p. 154.

34. Fearon and McWilliams, op. cit., Ref. 27, p. 128.

35. Sales, op. cit., Ref. 5, p. 201.

36. Fearon, op. cit., Ref. 27, p. 163.

37. Coulter, op. cit., Ref. 15, p. 139.

38. Wilford, op. cit., Ref. 23, p. 214.

39. Fearon and McWilliams, op. cit., Ref. 27, p. 133.

40. Coulter, op. cit., Ref. 13, p. 177.

41. McWilliams, op. cit., Ref. 4, p. 92.

42. Sales, op. cit., Ref. 5, p. 202.

43. Sales, ibid., p. 202.

44. E. Porter, 'Participatory democracy and the challenge of democracy across difference', in C. Roulston and

C. Davies (Eds), Gender, Democracy and Inclusion in Northern Ireland (London: Palgrave, 2000). 45. See, for example, S. O'Neill, Impartiality in Context: Grounding Justice in a Pluralist World (Albany, NY: State University of New York Press, 1997), and S. O’Neill, 'Liberty, equality and the rights of cultures: the marching controversy at Drumcree', British Journal of Politics and International Relations, 2/1 (2000), pp. 26-45. For a critique of O’Neill, see G. Newey, 'Discourse rights and the Drumcree marches: a reply to O'Neill', British Journal of Politics and International 
This is a post-print version of a paper that appears in The Journal of Political Ideologies 7(2):pp. 163-177, 2002.

Relations, 4/1 (2002) .

46. Porter, op. cit., Ref. 44, p. 148.

47. Porter, ibid., p. 148. A further example of the problems in Porter's deliberative model is her advocacy of 'quiet reflection' as part of dealing with what one hears from one's adversaries. A flippant response might

highlight the difficulty of such reflection in the background of sabre-rattling politicians, marching bands and rioting. In this context her belief that 'through reasoned debate, and motivated by the urgency to deliver a resolution that is acceptable to all different parties, judgement allows citizens and political representatives to listen, talk, consider other's views and allow themselves to be persuaded of the need to change' (Porter, op. cit., Ref. 44, p. 159) can only have value on an aspirational level.

48. E. Rooney, 'Women in Northern Irish politics: difference matters', in C. Roulston and C. Davies (Eds), Gender, Democracy and Inclusion in Northern Ireland (London: Palgrave, 2000), p. 166.

49. Sales, op. cit., Ref. 5, p. 194.

50. Coulter, op. cit., Ref. 13, p. 175.

51. Sales, op. cit., Ref. 5, p. 194.

52. C. Roulston, 'Democracy and the challenge of gender: new visions, new processes', in C.

Roulston and C. Davies (Eds), Gender, Democracy and Inclusion in Northern Ireland (London: Palgrave, 2000), p. 41.

53. Roulston, ibid., p. 42; Porter, op. cit., Ref. 44, pp. 151-152.

\footnotetext{
${ }^{1}$ In the 2001 General Election three women MPs were elected (Sylvia Hermon for the Ulster Unionists, Iris Robinson for the DUP and Michelle Gildernew from Sinn Fein). Women such as Bairbre de Brun (Sinn Fein) and Brid Rodgers (SDLP) have also established a high profile in the
} 
This is a post-print version of a paper that appears in The Journal of Political Ideologies 7(2):pp. 163-177, 2002.

Northern Ireland Assembly and the Northern Ireland Women's Coalition has played a pivotal role in the peace process.

2 See R.L. Miller, R. Wilford and F. Donoghue, Women and Political Participation in Northern Ireland, (Aldershot: Avebury, 1996).

${ }^{3}$ On the politics of difference, see I.M. Young, Justice and the Politics of Difference, (Princeton, NJ: Princeton University Press, 1990), A. Baumeister, Liberalism and the 'Politics of Difference', Edinburgh: Edinburgh University Press, 2000), and C. Roulston and C. Davies (eds) Gender, Democracy and Inclusion in Northern Ireland, (London: Palgrave, 2000).

${ }^{4}$ M. McWilliams, 'Women in Northern Ireland: an Overview', in E. Hughes (ed) Culture and Politics in Northern Ireland, Buckingham: Open University Press, 1991), p. 81.

${ }^{5}$. The term 'politics of avoidance' is used by R. Sales, Women Divided: Gender, Religion and Politics in Northern Ireland, (London: Routledge, 1997).

${ }^{6}$ Sales, ibid., p. 200.

${ }^{7}$ The dominance of the traditional divisions on political discourses in Northern Ireland is reflected in the analysis of power, conflict and emancipation in the province provided by Joseph Ruane and Jennifer Todd. Feminism is only mentioned within the paradigm of the traditional conflict and feminists are referred to as 'marginals' who have 'distanced themselves not simply from the dominant culture and politics of their community but from any politics specific to Northern Ireland or any attempt to reform a particularly "Northern Irish" political culture' (J. Ruane and J. Todd, The Dynamics of Conflict in Northern Ireland: Power, Conflict and Emancipation, (Cambridge:

Cambridge University Press, 1996), pp. 79-80).

${ }^{8}$ Sales, op cit., Ref. 5, p. 4

${ }^{9}$ See, for example, Roulston and Davies, op. cit., Ref. 3.

${ }^{10}$ See C. Mouffe, The Democratic Paradox, (London: Verso, 2000). See also A. Little, The Politics of Community: Theory and Practice, (Edinburgh: Edinburgh University Press, 2002) and A. Little, 'Community and Radical Democracy', Journal of Political Ideologies, 2002, forthcoming.

${ }^{11}$ See, for example, L. Nicholson (ed.), Feminism/Postmodernism, (London: Routledge, 1990), A. Phillips, Which Equalities Matter?, (Cambridge: Polity Press, 1999), and J. Freedman, Feminism, Buckingham: Open University Press, 2001).

${ }^{12}$ Sales, op. cit., Ref. 5, p. 9.

${ }^{13}$ See C. Coulter, 'Feminism and Nationalism in Northern Ireland', in D. Miller (ed.) Rethinking Northern Ireland: Culture, Ideology and Colonialism, (London: Longman, 1998).

${ }^{14}$ See some of the different experiences expressed in E. Fairweather, R. McDonough and M.

McFadyean, Only the Rivers Run Free, Northern Ireland: The Women's War, (London: Pluto Press, 1984).

${ }^{15}$ See C. Coulter, Contemporary Northern Irish Society, (London: Pluto Press, 1999).

${ }^{16}$ Coulter, op. cit., Ref. 13, p. 175; see also C. Hackett, 'Self-determination: the Republican Feminist Agenda', Feminist Review, 50 (1995), pp. 111-116.

${ }^{17}$ Coulter, op. cit., Ref. 13, p.175.

${ }^{18}$ Miller et al, op. cit., Ref. 2, p. 219. See also M. McWilliams, 'Struggling for Peace and Justice: Reflections on Women's Activism in Northern Ireland', Journal of Women's History, vol. 6, no. 4 (1995), pp. 13-39.

${ }^{19}$ Sales, op. cit., Ref. 5, p. 5.

${ }^{20}$ Sales, op. cit., Ref. 5, p. 175.

${ }^{21}$ Sales, op. cit., Ref. 5, p. 190.

${ }^{22}$ See the various contributions to Roulston and Davies, op. cit., Ref. 3, especially that of Elisabeth Porter.

${ }^{23}$ R. Wilford, 'Women and Politics', in P. Mitchell and R. Wilford (eds) Politics in Northern Ireland, (Oxford: Westview, 1999). 
This is a post-print version of a paper that appears in The Journal of Political Ideologies 7(2):pp. 163-177, 2002.

${ }^{24}$ Sales, op. cit., Ref. 5, p. 196.
${ }^{25}$ Sales, op. cit., Ref. 5, p. 170.
${ }^{26}$ Sales, op. cit., Ref. 5, p. 179.
${ }^{27}$ For discussions of the origins and participation of the NIWC, see K. Fearon 'Whatever Happened to the Women? Gender and Peace in Northern Ireland', in M. Cox, A. Guelke and F. Stephen (eds) A Farewell to the Arms? From 'Long War' to Long Peace in Northern Ireland, Manchester:

Manchester University Press, 2000), K. Fearon and M. McWilliams, 'Swimming Against the Mainstream: the Northern Ireland Women's Coalition', in C. Roulston and C. Davies (eds) Gender, Democracy and Inclusion in Northern Ireland, London: Palgrave, 2000), McWilliams, op. cit., Ref. 4, and M. McWIlliams and A. Kilmurray, 'Athene on the Loose: the Origins of the Northern Ireland Women's Coalition', Irish Journal of Feminist Studies, no. 2 (1997), pp.1-21.

${ }^{28}$ Fearon, op. cit., Ref. 27, p. 153.

${ }^{29}$ Fearon and McWilliams, op. cit., Ref. 27, p. 132.

${ }^{30}$ Fearon, op. cit., Ref. 27, pp. 154-156.

${ }^{31}$ Fearon, op. cit., Ref. 27, p. 157.

${ }^{32}$ Sales, op. cit., Ref. 5, p. 195.

${ }^{33}$ Fearon, op. cit., Ref. 27, p. 154.

${ }^{34}$ Fearon and McWilliams, op. cit., Ref. 27, p. 128.

${ }^{35}$ Sales, op. cit., Ref. 5, p. 201

${ }^{36}$ Fearon, op. cit., Ref. 27, p. 163.

${ }^{37}$ Coulter, op. cit., Ref. 15, p. 139.

${ }^{38}$ Wilford, op. cit. Ref. 23, p. 214.

${ }^{39}$ Fearon and McWilliams, op. cit., Ref. 27, p. 133.

${ }^{40}$ Coulter, op. cit., Ref. 13, p. 177.

${ }^{41}$ McWilliams, op. cit., Ref. 4, p. 92.

${ }^{42}$ Sales, op. cit., Ref. 5, p. 202.

${ }^{43}$ Sales, op. cit., Ref. 5, p. 202.

${ }^{44}$ E. Porter, 'Participatory Democracy and the Challenge of Democracy across Difference', in C. Roulston and C. Davies (eds) Gender, Democracy and Inclusion in Northern Ireland, (London: Palgrave, 2000).

${ }^{45}$ See, for example, S. O'Neill, Impartiality in Context: Grounding Justice in a Pluralist World, (Albany, NY: State University of New York Press, 1997) and S. O'Neill, 'Liberty, Equality and the Rights of Cultures: the Marching Controversy at Drumcree', British Journal of Politics and International Relations, vol. 2, no. 1 (2000), April, pp. 26-45. For a critique of O'Neill see G. Newey, 'Discourse Rights and the Drumcree Marches: a Reply to O'Neill', British Journal of Politics and International Relations, vol.4, no. 1 (2002), forthcoming.

${ }^{46}$ Porter, op. cit., Ref. 44, p. 148.

${ }^{47}$ Porter, op. cit., Ref. 44, p. 148. A further example of the problems in Porter's deliberative model is her advocacy of 'quiet reflection' as part of dealing with what one hears from one's adversaries. A flippant response might highlight the difficulty of such reflection in the background of sabrerattling politicians, marching bands and rioting. In this context her belief that 'through reasoned debate, and motivated by the urgency to deliver a resolution that is acceptable to all different parties, judgement allows citizens and political representatives to listen, talk, consider other's views and allow themselves to be persuaded of the need to change' (Porter, op. cit., Ref. 44, p. 159) can only have value on an aspirational level.

${ }^{48}$ E. Rooney, 'Women in Northern Irish Politics: Difference Matters', in C. Roulston and C. Davies (eds) Gender, Democracy and Inclusion in Northern Ireland, (London: Palgrave, 2000), p. 166.

${ }^{49}$ Sales, op. cit., Ref. 5, p. 194.

${ }^{50}$ Coulter, op. cit., Ref. 13, p. 175. 
This is a post-print version of a paper that appears in The Journal of Political Ideologies 7(2):pp. 163-177, 2002.

${ }^{51}$ Sales, op. cit., Ref. 5, p. 194.

${ }^{52}$ C. Roulston, 'Democracy and the Challenge of Gender: New Visions, New Processes', in C. Roulston and C. Davies (eds) Gender, Democracy and Inclusion in Northern Ireland, (London: Palgrave, 2000), p. 41.

${ }^{53}$ Roulston, ibid., p. 42; Porter, op. cit., Ref. 44, pp. 151-152. 


\section{University Library}

\section{- M M I N E R VA A gateway to Melbourne's research publications}

Minerva Access is the Institutional Repository of The University of Melbourne

Author/s:

LITTLE, ADRIAN

Title:

Feminism and the politics of difference in Northern Ireland

Date:

2002

Citation:

Little, A. (2002). Feminism and the politics of difference in Northern Ireland. The Journal of Political Ideologies, 7(2), 163-177.

Publication Status:

Published

Persistent Link:

http://hdl.handle.net/11343/34439 